УДК 342.9:351.74

DOI https://doi.org/10.32849/2663-5313/2020.8.24

Віталій Вдовічен,

докт. юрид. наук, доиент,

доиент кафедри публічного права

Чернівещького начіонального університету імені Юрія Федъковича

\title{
СУБСТАНЦІОНАЛЬНІ ЯКОСТІ ПРАВОВОЇ КАТЕГОРІЇ «ПОЛІЦЕЙСЬКІ ПОСЛУГИ»
}

Дослідження правової категорії «полічейські послуги» проведено з метою встановлення ї̈ субстаниіональних якостей, що сприятиме більш чіткому розумінню головних завдань Національної поліиї, які визначенні на нормативному рівні. Основна увага зосереджена на неоднозначному трактуванні як на доктринальному, так $і$ на нормативному рівні категорії «полічейсъкі послуги» та ї̈ прив'язаності до так званої публічної сервісної служби чи правоохоронної служби органів Національної поліиії. Поняття полічейських послуг розкривається як діяльність органів і посадових осіб Начіональної полічії України, змістом якої є здійснення на користь фізичних осіб та юридичних осіб, а також суспільства і держави в иілому відповідних заходів з метою забезпечення необхідних суспільно-правових та організачійно-управлінських умов для нормальної реалізачї ними своїх прав, свобод і законних інтересів, задоволення їхніх нагальних потреб у тих сферах суспільного життя, що належать до компетениії Національної полічії.

Використання на нормативному рівні категорії «поліцейські послуги» як нововведення створило чимало «незручностей» правозастосовного характеру, оскільки невизначеними залишаються їх перелік та види, порядок надання та сфери реалізащї, а також форми оцінювання ефективності надання поліиейсъких послуг.

Категорія «поліцейсъкі послуги» має поліструктурний характер: у широкому розумінні - будьяка діяльність Національної поліиї є поліщейською послугою, тобто поняття «поліцейські послуги» формується через визначення суб'єкта надання - Начіональну полічію; у вузькому розуміння розглядаються поліцейські послуги з точки зору змісту діяльності, і тут не охоплюються адміністративні й інформаційні послуги, що надаються поліиією. Основною метою полічейських послуг, яка розкриває їх субстанціональні якості, варто визначати результати, яких прагне досягти суспільство і публічна влада, наділяючи органи Начіональної полічї̈ відповідними функціями як сервісного, так і правоохоронного характеру через відповідні обов'язки і права щодо надання ними зазначених послуг. До таких послуг відносимо забезпечення публічної безпеки і порядку; охорону прав $і$ свобод людини, інтересів суспільства і держави; протидію злочинності, а також допомогу особам, які з особистих, економічних, сочіальних причин або внаслідок надзвичайних ситуацій потребують такої допомоги.

Ключові слова: публічні послуги, поліцейські послуги, сервісна функція поліції, публічносервісна діяльність.

Постановка проблеми. Адекватними інструментами для аналізу суспільного відношення в цілому та правового відношення зокрема $\epsilon$ філософські категорії «змісту» та «форми». Методологічні можливості цих категорій дозволяють з'ясувати субстанціональні якості правовідношення в цілому, найважливіші якості його компонентів та зв'язку між ними, але не більше. Адже виділення у правовідношенні ще якихось речей, крім змісту, форми та зв'язку між ними, наприклад елементів, складу, структури, на доповнення до його змісту і форми стає некоректним у загальнофілософському плані, оскільки зміст та форма вичерпують явище повністю й, окрім них та зв'язку між ними, у жодному суспільному відношенні нічого немає. Ось у такому ракурсі постає і дилема визначення категорії «поліцейські послуги». Річ у тому, що одним із фундаментальних нововведень, які встановлює Закон України «Про Національну поліцію», є переорієнтація характеру роботи даного органу державної влади - із карально-репресивного на сервісний публічний суб'єкт. Вказаний закон особливо підкреслює, що поліція повинна саме надавати послуги, тобто здійснювати сервісну публічну діяльність. Зважаючи на те, що поліцейські послуги $€$ «новинкою» і для українського суспільства, і для українського законодавства, доречним $є$ питання визначення особливостей даной категорії, але ще важливішим виступає з'ясування іiі субстанціональних якостей, які покликані розкрити початкове значення, мету та доцільність запровадження категорії 
«поліцейські послуги» у вітчизняне законодавство.

Аналіз останніх досліджень. Поліцейські послуги є частиною більш широкої правової категорії «публічні послуги», які на теоретичному рівні можна вважати вже досить опрацьованими. Основними ознаками публічних послуг є те, що вони: по-перше, забезпечують загальнозначущу діяльність; по-друге, мають необмежене коло суб'єктів надання (як правило, органи публічного управління); по-третє, поєднують як публічний, так і приватний інтерес [1, с. 176]. Проте невизначеність поняття «поліцейська послуга» в українському законодавстві та відсутність чіткого розуміння цієї категорії серед науковців створюють перешкоди в процесі правозастосування й унеможливлюють ефективне виконання працівниками поліції своїх обов'язків. Адже особливо складно визначити, де межі функціонального обов'язку поліції, а де починається її сервісна діяльність [2, с. 187].

Разом із тим науковці не набули єдності в розумінні вказаної категорії. I тут ідеться не лише про сам зміст «поліцейської послуги», а є проблема визначення специфіки публічно-сервісної діяльності Національної поліції. Так, для прикладу, варто відзначити в такому ракурсі напрацювання О. М. Калюк, яка визначає: «публічно-сервісна діяльність поліції - це діяльність 3 обслуговування потреб та інтересів приватних осіб у їхніх стосунках 3 органами публічної адміністрації - органами внутрішніх справ» [3, с. 3]. У такому ж ракурсі розмірковує і В. А. Троян: «Публічно-сервісна діяльність - це діяльність державних інституцій щодо надання публічних послуг», а публічно-сервісна діяльність Національної поліції «пов'язана з видачею документів дозвільного характеру щодо вогнепальної зброї, боєприпасів, інших предметів;.у сфері дорожнього руху; у сфері охоронної діяльності (охорона майна громадян, організацій, а також об'єктів, що підлягають обов'язковій охороні, тощо)» [4, с. 91, 93].

Також варта уваги позиція О. Банчук: «Сервісна функція поліції - це не просто боротьба зі злочинністю, забезпечення правопорядку, а саме надання послуг суспільству щодо підтримки належного рівня безпеки» [5].

Досліджуючи поліцейські послуги, Д. Ластович акцентує увагу на необхідності визначення мети запровадження «поліцейських послуг» у діяльність поліції [6, с. 141].

А от в аспекті реалізації завдань Національної поліції А. Овчаров наголошує, що «не варто поліцію перетворювати в суцільне бюро з надання певних послуг» [7].
Коректним, на наш погляд, є твердження Д. Йосифович, за яким «послуги, що надає Національна поліція, виконуючи свої основні завдання, визначені Законом України «Про Національну поліцію», слід вважати поліцейськими, а послуги, що надаються Національною поліцією та МВС у сфері внутрішніх справ, 3 метою створення умов для реалізації фізичними та юридичними особами прав, свобод і законних інтересів за їх заявою, доцільно вважати сервісними» [8, c. 134].

Досить радикальну позицію зайняв I. Зозуля, стверджуючи, що одним із можливих, але дискусійних шляхів вирішення проблеми було би вилучення із Закону України «Про Національну поліцію» та суміжного законодавства терміна «поліцейські послуги», обмежившись загальною вказівкою, що Національна поліція у своїй діяльності надає в межах законодавства в тому числі і сервісні послуги, зміст, перелік та порядок надання яких визначено законом. Варіант збереження в інституційному законодавстві терміна «поліцейські послуги» натепер пов'язаний з поки ще складною перспективою перегляду законодавчого, наукового та практичного, в тому числі й міжнародного, досвіду щодо сервісної діяльності Національної поліції України [9].

| Постановка завдання. Враховуючи сучасний стан «реформування» сфери забезпечення громадського порядку, де активними учасниками виступають органи Національної поліції, особливо актуальним постає визначення основних субстанціональних властивостей категорії «поліцейські послуги», яка заявлена як основне завдання Національної поліції, тобто це те, заради чого створюється і функціонує даний орган державної влади.

Виклад основного матеріалу. Введення нового терміна «надання послуг» дало змогу зробити значний крок до переосмислення ролі, завдань і призначення Національної поліції, наближення її діяльності до європейських стандартів. Це має сприяти покращанню реагування на всі звернення громадян, поліпшенню виконання публічносервісної функції поліції шляхом надання якісних послуг населенню. Фактично саме на це вказує стаття 2 Закону України «Про Національну поліцію», зокрема, сферами «надання поліцейських послуг» проголошено усю галузь діяльності поліції: забезпечення публічної безпеки і порядку; охорону прав і свобод людини, а також інтересів суспільства і держави; протидію злочинності; надання в межах, визначених законом, 
послуг з допомоги особам, які з особистих, економічних, соціальних причин або внаслідок надзвичайних ситуацій потребують такої допомоги [10]. Однак, як відзначає І. Зозуля, фактично перша 3 них - сфера «забезпечення публічної безпеки і порядку» - кваліфікується як простір для надання суспільству Національною поліцією поліцейських послуг. Але, як будь-які послуги, вони можуть надаватись тільки тоді, коли на них $€$ попит: у нашому випадку є замовник - суспільство - та $є$ виконавець - Національна поліція [9, с. 22].

Звичайно, буквальне тлумачення статті 2 вказаного Закону ставить під сумнів такі субстанціональні ознаки публічних послуг, як: індивідуалізація, тобто пов'язаність 3 особою виконавця та процесом вчинення ним певних дій (здійснення певної діяльності); ініціювання надання послуги виключно споживачем. Забезпечення публічної безпеки і порядку, протидія злочинності та охорона прав і свобод людини не є діяльністю «на замовлення» конкретної особи, хоча в окремих ситуаціях така модель є допустимою. Якщо таку діяльність вважати послугою, то «вигодоотримувачем» є не окрема людина, а суспільство в цілому [11, с. 72$]$.

Категорія «поліцейська послуга» реалізує себе як передбачена законом публічновладна діяльність органу поліції, безпосередньо пов'язана із забезпеченням прав і свобод людини, інтересів суспільства і держави, протидією злочинності, підтриманням публічної безпеки і порядку, та виражається в здійсненні дій та прийнятті рішень відповідною уповноваженою особою.

Поліцейські послуги можна розглядати у широкому розумінні: будь-яка діяльність Національної поліції є поліцейською послугою. 3 точки зору цього підходу поняття «поліцейські послуги» формується через визначення суб'єкта надання - Національну поліцію. Якщо ж розглядати поліцейські послуги з точки зору змісту діяльності, отримуємо значно вужчу категорією, яка не охоплює адміністративні й інформаційні послуги, що надаються поліцією. У вузькому розумінні поліцейські послуги - це надання в межах, визначених законом, послуг з допомоги особам, які з особистих, економічних, соціальних причин або внаслідок надзвичайних ситуацій потребують такої допомоги [11, с. 73].

Однак все ж таки варто точно визначити, чи можлива діяльність Національної поліції, наприклад, з охорони інтересів суспільства і держави розглядатись як поліцейська послуга. I тут вдало відзначив I. Зозуля, що, скоріше, це категорія обов'язків Наці- ональної поліції, яких остання фактично уникає, прикриваючись «послугами» [9]. Тому, розкриваючи субстанціональні якості категорії «поліцейські послуги», не можна оминути увагою мету такої категорії, основні завдання таких послуг, тобто для чого і чи можливо без них. Напевно це питання було б риторичне, однак не завжди законодавчі нововведення наповнюються правовим змістом, де чітко простежується ї мета. У загальному розумінні мета - це уявна модель бажаного результату, те, до чого прагнуть суб'єкти процесу. Як зазначає Д. Ластович, дослідження варто розпочати 3 визначення мети запровадження «поліцейських послуг» у діяльність поліції: під метою запровадження поліцейських послуг слід розуміти той результат (результати), якого (яких) прагне досягти влада, наділяючи органи внутрішніх справ відповідними функціями та повноваженнями щодо надання ними зазначених послуг [6, с. 141].

Водночас поліцейські послуги не є кінцевим результатом діяльності поліції, вони можуть визнаватися послугами лише з точки зору розуміння їх як процесу, або нерозривної єдності діяльності і результату, що споживається в процесі його створення. Підтверджує такий підхід до визначення поліцейської послуги необхідність систематичності та безперервності протидії злочинності та забезпечення публічної безпеки. Тому це свідчить про необхідність перегляду вибраного в законодавстві підходу з метою усунення суперечливого сприйняття елементів єдиної системи публічних послуг.

Фундаментальними цілями запровадження поліцейських послуг, які розкривають їх субстанціональну природу, можна назвати такі. Перш за все це функціонування поліції як захисника прав і свобод людини, а також прав і законних інтересів суспільства, як це, власне кажучи, і повинно бути у сучасній демократичній державі. За умов переважання радянського (етатистського) підходу до розуміння суспільного призначення міліції та організації іï роботи реальне втілення даної мети було неможливим. Однак сьогодні, коли владою змінено парадигму розвитку органів внутрішніх справ та звернено увагу на потужний світовий досвід у цій сфері, є усі підстави вважати, що означена мета все ж таки буде реалізована, хоча б частково. Наступне - це повернення довіри населення насамперед шляхом наближення правоохоронців до громадян через їх максимальне залучення до роботи на вулицях, а не в кабінетах і водночас забезпечення високого рівня мобільності та оснащеності поліцейських. Крім того, варто оптимізувати 
організаційно-функціональну та штатну структури поліцейських сил, а також витрати на їх утримання.

Таким чином, створення поліції саме як сервісної служби відображає прагнення влади змусити правоохоронну систему служити інтересам окремих громадян і суспільства в цілому, захищати та сприяти їх нормальній реалізації. Однак єдине завдання, що повною мірою вписується у вже існуючу концепцію публічних послуг, - це надання допомоги особам, що іï потребують. Проте, на жаль, вичерпного переліку форм та умов надання такої допомоги поки що не вироблено і нормативно не закріплено. До поліцейських заходів, передбачених Законом, спрямованих на реалізацію цього завдання, можна віднести поліцейське піклування [11, с. 74].

Завдання Національної поліції - це визначені на законодавчому рівні конкретні проблеми, що мають бути вирішені шляхом надання поліцейських послуг. Згідно зі статтею 2 Закону України «Про Національну поліцію», основним завданням поліції $€$ надання поліцейських послуг, тому національна поліція виконує такі функції. По-перше, забезпечує публічну безпеку і порядок, тобто поліцейські послуги спрямовані на захист життєво важливих інтересів суспільства, сконцентрованих у його матеріальних і духовних цінностях, від джерел небезпеки природного та (або) штучного характеру.

По-друге, забезпечує охорону прав і свобод людини, а також інтересів суспільства і держави. Дане завдання передбачає реалізацію органами і посадовими особами комплексу організаційно-правових заходів, спрямованих на захист прав, свобод і законних інтересів фізичних осіб, а також прав і законних інтересів суспільства та держави від протиправних посягань; забезпечення безпечних умов для їх (прав, свобод і законних інтересів) нормальної та безперешкодної реалізації.

По-третє, забезпечення протидії злочинності. У рамках зазначеного завдання поліція здійснює комплекс організаційно-правових, управлінських та виховних заходів, спрямованих на виявлення й ліквідацію наявної у суспільстві злочинної активності, усунення їі шкідливих наслідків, виявлення та усунення умов і факторів, що сприяють виникненню та процвітанню злочинності.

По-четверте, забезпечення надання допомоги особам, які з особистих, економічних, соціальних причин або внаслідок надзвичайних ситуацій потребують такої допомоги. Виконання національною поліцією цього завдання передбачає надання побутової, правової, домедичної та (або) психологічної допомоги фізичним особам, які потрапили у екстрену ситуацію чи з інших причин потребують такої допомоги і не мають змоги отримати їі з інших джерел. Зазначений напрям поліцейських послуг досить яскраво підкреслює переорієнтацію національної поліції саме на її ефективну взаємодію із суспільством шляхом надання населенню відповідної допомоги.

\section{Висновки}

Надання поліцейських послуг у сфері охорони прав і свобод людини, а також інтересів суспільства і держави є об'єктивно необхідним та дуже важливим напрямом діяльності Національної поліції. Значення даних послуг полягає у тому, що вони дозволяють індивідуальним та колективним суб'єктам, у тому числі державі і суспільству в цілому, в разі виникнення у них потреби посилити рівень безпеки певних своїх прав, свобод та законних інтересів, уклавши угоду про надання відповідних охоронних послуг 3 поліцією охорони.

Натепер немає чіткої універсальної формули оцінювання ефективності та якості надання поліцейських послуг, оскільки кожна із них має як свої переваги, так і прогалини. I така ситуація не дає можливості зробити об'єктивні висновки $з$ даного приводу. Тому для формування достовірного уявлення про рівень ефективності надання поліцейських послуг необхідно враховувати ступінь чіткості та формальної визначеності субстанціональних якостей таких послуг насаперед це чітке їхнє визначення на нормативному рівні.

\section{Список використаних джерел:}

1. Амосов О. Ю. «Послуга» при розгляді звернень громадян : економічна та правова категорія. Теорія та практика державного управління : зб. наук, праць. Харків: Вид-во ХарРІ НАДУ «Магістр». 2010. Вип. 1 (28). С. 175-180.

2. Циганов О. Г. Підходи до з'ясування сутності поліцейських послуг: вітчизняні реалії та зарубіжна практика. Вісник Луганського державного університету внутрішніх справ імені Е.О. Дідоренка. 2019. № 1. С. 186-193.

3. Нова поліція: сервісна служба чи інститут боротьби із злочинністю? URL: http://uire.org.ua/ publikatsiyi/nova-politsiya-servisna-sluzhba-chiinstitut-borotbi-iz-zlochinnistyu. 02.07.2016. (дата звернення: 28.07.2020).

4. Троян В. А. Поняття та види публічно-сервісної діяльності Національної поліції України. Право і безпека. 2016. № 4. С. 90-94.

5. Банчук А. Новый закон о полиции. Как ограничивают права украинцев. URL: https:// 
nv.ua/opinion/novyj-zakon-o-politsii-kakogranichivajut-prava-ukraintsev-66668.html. 02.09.2015. (дата звернення: 24.07.2020).

6. Ластович Д. М. Місце та значення поліцейських послуг в діяльності національної поліції. Форум права. 2016. № 1. С. 141-146.

7. Овчаров А. Чому не всі завдання поліції мають реалізовуватися шляхом надання поліцейських послуг. URL: https://vilneslovo.com/ chomu-ne-vsi-zavdannya-policziï-povinnirealizovuvatisya-shlyaxom-nadannyapoliczejskixposlug. (дата звернення: 12.07.2020).

8. Йосифович Д. Надання адміністративних послуг Міністерством внутрішніх справ України та Національною поліцією. Вісник Наиіонального університету «Львівська політехніка». Серія
«Юридичні науки». Львів: Видавництво Львівської політехніки, 2017. № 876. С. 131-137.

9. Зозуля І. В. Поліцейські послуги в законодавстві України та на практиці. Форум Права. 2019. № 56 (3). C. 21-38. DOI: http://doi.org/ 10.5281/zenodo.3362208.

10. Про Національну поліцію України : Закон України в редакиї̈ від 22.04.2020. Офіиійний вісник Украйни. 2015. № 63. С. 33. Ст. 2075, код акта 78051.

11.Біла-Тюріна Ю. 3. Ознаки поліцейських послуг та іх характеристики. Традищіi та новаиї юридичної науки: минуле, сучасність, майбутнє : матер. Міжнар. наук.-практ. конф. (м. Одеса, 19 травня 2017 р.) : у 2-х т. 2017. T. 2. C. $72-74$.

Vitalii Vdovichen. Substancial qualities of the legal category "police services"

The research of the legal category «police services» was carried out in order to establish its substantial qualities. This will contribute to a clearer understanding of the main tasks of the National Police, which are defined at the regulatory level. The main points of attention are focused on the existence of an ambiguous interpretation of the category «police services» both at the doctrinal and normative levels. In addition, it is often emphasized that this category is attached to the so-called public service or law enforcement service of the National Police. The concept of police services is defined as the activities of bodies and officials of the National Police of Ukraine. The content of such activities is the implementation of appropriate measures for the benefit of individuals and legal entities, society and the state. The main purpose of such activities is to provide the necessary social-legal and organizational-managerial conditions for the normal realization of their rights, freedoms and legitimate interests. At the same time, satisfaction their urgent needs in those areas of public life that fall within the competence of the National Police.

At the regulatory level, the use of the category «police services» as an innovation has created many «inconveniences» of law en forcement nature, as theirlist and types, the procedure and scope of implementation, as well as forms of assessing the effectiveness of police services remain unclear.

The category «police services» has a polystructural character. In a broad sense, any activity of the National Police is a police service, the concept of «police services» is formed through the definition of the subject of provision - the National Police. In a narrow sense, police services are considered in the perspective of the content of activities and do not cover administrative and information services provided by the police. We mean the provision of assistance services to persons in need of such assistance for personal, economic, social reasons or as a result of emergencies within the limits set by law - this is a narrow understanding of the category of «police services».

The main purpose of police services, which reveals their substantial qualities, is to determine the results that society and public authorities seek to achieve. Therefore, the National Police receive appropriate service and law enforcement functions through their respective responsibilities and rights to provide those services. Such services include ensuring public safety and order; protection of human rights and freedoms, the interests of society and the state; crime prevention, assistance to persons who need such assistance for personal, economic, social reasons or as a result of emergencies.

Key words: public services, police services, police service function, public service activity. 